\title{
ACTIVE CASE FINDING: COMMUNITY HEALTH WORKERS' ACTIVITY RELATED TO TUBERCULOSIS CONTROL IN A LARGE CITY, BRAZIL
}

\author{
Beatriz Estuque Scatolin ${ }^{1}$, Erika Simone Galvão Pinto ${ }^{2}$, Ricardo Alexandre Arcêncio ${ }^{3}$, Rubia Laine de Paula \\ Andrade ${ }^{4}$, Anneliese Domingues Wysocki ${ }^{5}$, Maria Amélia Zanon Ponce ${ }^{6}$, Tiemi Arakawa ${ }^{7}$, Aline Ale Beraldo ${ }^{8}$, \\ Tereza Cristina Scatena Villa9 ${ }^{9}$ Pedro Fredemir Palha ${ }^{10}$
}

${ }^{1}$ Doctoral student. Interunit Ph.D. Program in Nursing, University of São Paulo at Ribeirão Preto College of Nursing (EERPUSP). Sao Paulo, Brazil. Email: scatolin@eerp.usp.br

${ }^{2}$ Ph.D. in Nursing. Professor at the Universidade Federal do Rio Grande Norte. Rio Grande do Norte, Brazil. Email: erikasgp@ gmail.com

${ }^{3}$ Ph.D. in Nursing. Assistant Professor, Maternal-Infant Nursing and Public Health Department, EERP/USP. São Paulo, Brazil. Email: ricardoarcencio@uol.com.br

${ }^{4}$ Ph.D in Health Sciences. Laboratory Specialist, Maternal-Infant Nursing and Public Health Department, EERP/USP. São Paulo, Brazil. Email: rubia@eerp.usp.br

${ }^{5}$ Doctoral student, Interunit Ph.D. Program in Nursing, EERP-USP. São Paulo, Brazil. Email: lilisew@yahoo.com.br

${ }^{6}$ Ph.D in Health Sciences. Professor of Nursing and Medicine at the Ceres Faculty (FACERES). São Paulo, Brazil. Email: amelinha_famerp@yahoo.com.br

${ }^{7}$ Doctoral student. Public Health Nursing Program, EERP/USP. São Paulo, Brazil. Email: tiemi.a@gmail.com

${ }^{8}$ Doctoral student. Interunit Ph.D. Program in Nursing, EERP-USP. São Paulo, Brazil. E-mail: li_abb@yahoo.com.br

${ }^{9}$ Ph.D. in Nursing. Professor, Maternal-Infant Nursing and Public Health Department, EERP/USP. São Paulo, Brazil. Email: tite@eerp.usp.br

${ }^{10}$ Ph.D. in Nursing. Senior Professor, Maternal-Infant Nursing and Public Health Department, EERP/USP. São Paulo, Brazil. Email: palha@eerp.usp.br

\begin{abstract}
This study analyzed the Community Health Workers' activity in active case finding in Ribeirão Preto-SP. Cross sectional study, conducted in 2009-2010, with the use of a structured form, which was applied to 105 Community Health Workers and research of secondary data. Indicators were created based on the variable means that used the Likert scale for the answers, being dissatisfactory (scores 1 and 2), regular (3) and satisfactory (4 and 5). Deficiencies in the activity of the Community Workers in the active case finding were identified (mean=3.0), in the discussion with the community about the tuberculosis (mean=1.5) and in the establishment of partnership in the region for the active case finding (mean=1.9). Only $6 \%$ of the expected respiratory symptoms in the areas where the units of the participants are located were examined. The results reinforced the need for nursing supervision, a new work logic, with advances in the intersectional articulation, aimed at increasing the detection of tuberculosis cases.
\end{abstract}

KEYWORDS: Community health workers. Epidemiological surveillance. Tuberculosis. Nursing.

\section{BUSCA DE PACIENTES SINTOMÁTICOS RESPIRATÓRIOS: ATUAÇÃO DO AGENTE COMUNITÁRIO DE SAÚDE NO CONTROLE DA TUBERCULOSE EM MUNICÍPIO DE GRANDE PORTE, BRASIL}

\begin{abstract}
RESUMO: Este estudo analisou a atuação do Agente Comunitário de Saúde na busca de sintomáticos respiratório em Ribeirão Preto-SP. Trata-se de estudo de corte transversal, realizado em 2009-2010, através de formulário estruturado aplicado a 105 Agentes Comunitários de Saúde e consulta a dados secundários. Criou-se indicadores a partir das médias das variáveis que apresentaram escala Likert de resposta, sendo insatisfatório (valor 1 e 2), regular (3) e satisfatório (4 e 5). Verificaram-se deficiências na atuação do Agente Comunitário na investigação dos sintomáticos respiratórios (média $=3,0$ ), na discussão sobre tuberculose com a comunidade (média $=1,5$ ) e no estabelecimento de parcerias no território para a busca de sintomáticos respiratórios (média=1,9). Apenas $6 \%$ dos sintomáticos respiratórios esperados nas áreas adscritas das unidades dos entrevistados foram examinados. Os resultados reforçam a necessidade de supervisão de enfermagem, uma nova lógica de trabalho, com avanços na articulação intersetorial, visando o incremento na detecção de casos de tuberculose.
\end{abstract}

PALAVRAS CHAVE: Agentes comunitários de saúde. Vigilância epidemiológica. Tuberculose. Enfermagem. 


\section{BÚSQUEDA DE PACIENTES SINTOMÁTICOS RESPIRATORIOS: ACTUACIÓN DEL AGENTE COMUNITARIO DE SALUD EN EL CONTROL DE LA TUBERCULOSIS EN UNA MUNICIPALIDAD GRANDE DE BRASIL}

RESUMEN: Este estudio examinó el papel del Agente Comunitario de Salud en la búsqueda de pacientes sintomáticos respiratorios en Ribeirão Preto-SP. Estudio transversal, realizado en 2009 utilizando formulario aplicado a 105 Agentes Comunitarios de Salud y consulta de datos secundarios. Los indicadores fueron creados a partir de medias de cuestiones que presentaron escala de respuesta tipo Likert, que se evaluó como insatisfactorio (valor de 1 y 2), regular (3), satisfactorio (4 y 5). Hubo deficiencias en el desempeño en búsqueda de sintomáticos respiratorios (media $=3,0)$, discusión con la comunidad (media $=1,5$ ) y establecimiento de asociaciones en el territorio para búsqueda de sintomáticos respiratorios (media $=1,9$ ). Sólo $6 \%$ de los sintomáticos respiratorios esperados en las áreas de estudio fueron examinados. Se refuerza la necesidad de la enfermería en supervisión de los Agentes Comunitarios, una nueva lógica de trabajo, con avances en la coordinación intersectorial, teniendo como objetivo el aumento de detección de casos.

PALABRAS CLAVE: Agentes comunitarios de salud. Vigilancia epidemiológica. Tuberculosis. Enfermería.

\section{INTRODUCTION}

In the context of the reorganization of the care practices in relation to tuberculosis (TB) in Brazil, the National Plan for TB Control has emphasized the integration of the actions for control of the disease to the Primary Health Care (PHC), particularly through the Family Health Strategy (FHS) and the Community Health Workers Program (CHWP). ${ }^{1}$ From this perspective, an interaction among the care practices in relation to TB , more delineated by the particularities and emerging health needs in the territory, is expected, representing a break up with the programmatic logic for the healthcare planning focused on the situational diagnosis of the communities. ${ }^{2}$

In this sense, Community Health Workers (CHWs) take the lead in this process due to their presence in the region and by sharing the same social and cultural context and the same linguistic universe, capable of promoting the articulation between the healthcare services and the community, identifying their problems, and acting in the prevention of diseases and promotion of health, ${ }^{3-5}$ which may be an important contribution in TB control.

Through a literature review of the past 20 years, 15 published articles about the work of the CHWs related to TB control were identified, and it was found that, the participation of this professional predominantly involves the promotion of knowledge in the communities about the disease, the effectiveness of prevention actions, the increase of access, acceptability and adherence to TB treatment, as well as in the cure rates. ${ }^{6-9}$ Despite being one of the objectives of the CHWs' work, only few studies have addressed the role of these workers in the Active Case Finding (ACF); they are faced difficulties in the development of such action, ${ }^{10-12}$ showing that this requires knowledge beyond the technical aspects and that there is a need to incorporate a broad view of the health-disease process and their determinants in so far as they have a very close relationship with the community.

Therefore, the CHWs have an important role in TB control, since their work involves options for expanding the Respiratory Symptoms (RS) access to the healthcare services, leading to early diagnosis and reduction of morbidity and mortality in the community, caused by TB. This article was aimed at analyzing the work of CHWs in relation to ACF in Ribeirão Preto-SP.

\section{METHODS}

This is a descriptive, cross sectional study, which is part of the multicenter project entitled "Delay in the diagnosis of tuberculosis: analysis of the causes in different regions of Brazil", approved and funded by the CNPq - Notice MCT/CNPq/ CT Saúde/MS/SCTIE/DECIT 30/2008 Doenças Negligenciadas - Proc. 575386/2008-8.

The study was conducted in the city of Ribeirão Preto, São Paulo, which had a population of approximately 563,107 inhabitants in 2009. The City Healthcare Network is organized into five health districts (North, South, East, West and Central) with a total of 13 Family Health Units (FHUs) and 28 Primary Healthcare Units (PHUs), and 20 of them have a CHWP. Ribeirão Preto is served by $13 \%$ of FHU and $35 \%$ of CHWs. ${ }^{13}$ This service is not homogeneous among the districts. The South and Central Districts do not have FHUs, and eight of them are located in the West District and four in the North District, areas with more vulnerability and concentration of TB cases, and which also have more $\mathrm{CHWs}^{\prime}$ coverage. Of the 13 healthcare units that participate in the study, three of the four studied FHUs have the nursing 
supervision of six CHWs for one nurse $(6: 1)$, and of the nine studied PHUs / CHWPs, six have nursing supervision (15:1), which is in accordance with the rules of the Ministry of Health, ${ }^{14}$ as well as the number of people monitored by the CHWs (750 by one $\mathrm{CHW}$ ).

Regarding the TB epidemiology, the city had 194 cases of TB in 2009, which means an incidence rate of $32.7 \%$ per 100,000 inhabitants and $20 \%$ of infection by both TB and HIV, The care to TB patients is provided at secondary level in five TB reference outpatient care units, which are spread in the health districts and work with specialized teams and perform actions for the diagnosis and clinical management of the cases and their contacts. All the outpatient care units can perform smear microscopy and sputum culture. The laboratories responsible for the analysis of these exams have partnerships with the City Health Council (CHC), and the samples of the exams are collected in most FHUs and PHUs around three times a week, in the mornings. The results are available in the electronic records automated system Hygia-WEB, which can be accessed online in all the healthcare units and, if the results are positive, the laboratory informs the healthcare service by phone.

The study population was composed of CHWs who were working at the FHUs and PHUs of Ribeirão Preto in April 2009. In this period, there were 333 active CHWs. For the calculation of the sample, a sampling error of 0.08 was considered, $\mathrm{Z}$ of 1.96 for a $95 \%$ confidence interval, population proportion of $50 \%$ and correction for the population size of 333 people, obtaining 105 $\mathrm{CHWs}$. The process of sampling was performed through a proportional distribution of the health districts. The sampling was intentional and carried out through a draw to determine the order of the healthcare units to participate in the study. For each unit drawn, all of the CHWs present in the healthcare unit at the time of collection were interviewed. This occurred until the sample proportion to each district was completed.

The data collection period was from June 2009 to January 2010. Initially, after the draw of the healthcare units for data collection, the research proposal was presented and a team of trained interviewers started the data collection in the units under the supervision of the researchers.

Of the CHWs who were working in the services at the time of data collection, 14 were not interviewed because they were performing activities out of the service, and two did not agree to participate in the research. If the expected number of interviews was not completed, a new healthcare service was drawn, totaling 13 healthcare units studied. In this sense, based on the proportional distribution by health district, $30 \mathrm{CHWs}$ from the North district, six from the South, 18 from the East, 48 from the West and three from the Central district participated in the study.

Data collection was carried out through a structured questionnaire, developed and based on previous studies, handbooks and manuals of the Ministry of Health, which provided support for the creation of indicators related to the ACF related to $\mathrm{TB}$ in the practice of CHWs. ${ }^{10-12,15-16}$

This structured questionnaire involved 19 questions, divided into two sections, as follows:

I - Characterization of the CHWs: it included seven questions related to gender, level of education, type of unit they work in, participation in training about TB; and skills to identify suspects and provide advice about TB and sputum collection.

II - Work of the CHWs in the ACF: included 12 questions, covered in Table 1 . These variables were organized into two dimensions, one of them being individual care, expressing the care focused on the ACF practice in the individual scope, and the other one being collective care, with variables related to the collective actions. These dimensions are important interfaces in the attempt to control the determinants of the health-disease process and thus the integral care of the population in the territory. ${ }^{17}$

The participants answered each question of the questionnaire with dichotomous, ordinal qualitative answers and a pre-established scale of possibilities, the Likert scale, to which a score of one to five was attributed for the degree of preference or agreement of the statements (1- never; 2 - almost never; 3- sometimes; 4- almost always; 5- always). It can be highlighted that, after the interviews, the questionnaires were revised, in order to identify gaps in their completion.

The variables that sought to characterize the CHWs interviewed were analyzed based on the descriptive statistics. The other variables with Likert scale of answers were evaluated based on the development of indicators that corresponded to the mean value of the scores, which were considered unsatisfactory for values close to 1 and 2 , regular for values close to 3 and satisfactory for values close to 4 and 5 . For these values, the confidence interval was calculated at $95 \%$. 
Table 1 - Work variables of the CHWs in the search for respiratory symptoms based on individual and collective care, june 2009 - jan 2010

\begin{tabular}{|c|c|c|}
\hline Section & Dimension & Variables \\
\hline \multirow{12}{*}{$\begin{array}{l}\text { Work of CHWs } \\
\text { in the ACF }\end{array}$} & \multirow{7}{*}{ Individual care } & A - Identification of the RS of TB in the community and healthcare services \\
\hline & & B - Investigation of RS through home visits \\
\hline & & C -Taking a smear microscopy referral to users in their territory \\
\hline & & D - Showing users how to collect sputum \\
\hline & & E - Showing users how to store and send the sputum jar \\
\hline & & F - Informing nurses about the RS identified in their territory \\
\hline & & G - RS investigation based on confirmed cases of TB in the community \\
\hline & \multirow{5}{*}{ Collective care } & $\mathrm{H}$ - Partnership with the community in the ACF \\
\hline & & I - Discussion with the community about TB \\
\hline & & J - Health education about TB within the community \\
\hline & & K - Participation in discussions with the team about actions to control the disease \\
\hline & & $\begin{array}{l}\text { L - Support from other healthcare professional working in the same service in a } \\
\text { situation of suspected TB }\end{array}$ \\
\hline
\end{tabular}

The proportion of RS examined was also calculated, since it is understood that this indicator reflects an integrated work that is focused on actions of health surveillance that is the outcome of the efforts of the team in the ACF, especially of the CHWs, who mainly work in the territory. For such, the number of diagnosed smear microscopies requested by the studied healthcare units was gathered at the local laboratory, with an enrolled population of 184,408 inhabitants. As expected number of RS, the national parameter of $1 \%$ of the population was adopted. ${ }^{16}$

The project underwent a pilot study, in which 15 interviews were preformed, and was authorized by the CHC of Ribeirão Preto, with the approval of the Research Ethics Committee of the University of São Paulo at Ribeirão Preto College of Nursing, according to opinion n. 0984/2008. For this study, the ethical principles of research involving human beings were complied with, as per the Helsinki Declaration and Resolution n. 196/96 and n. 251/97 of the National Health Council.

\section{RESULTS}

Of the CHWs interviewed, 68 (65\%) worked in PHUs with CHWP and 37 (35\%) in FHUs. There was predominance of female $(99 \%)$ and most of them $(69 \%)$ had completed high school. It was identified that $55 \%$ of the CHWs in the study al- ways participated in training about TB, and $61 \%$ of them stated to be always capable of developing initiatives related to ACF, $79 \%$ stated to always be capable of providing advice about TB and $65 \%$ stated to be capable of providing advice concerning sputum collection.

As for the work of the CHWs in the ACF in the individual care dimension, there was weaknesses in the investigation of cough at the home visits (mean=3.0). However, the CHWs had satisfactory scores in the identification of the RS of TB in the community and healthcare services (mean=3.9), and in the investigation based on the index cases (mean=3.9). It can be noted that the CHWs inform the nurses about the cough symptom (mean=4.5), but do not provide the sputum jar to the RS (mean=1.8). Also in relation to individual care, the skills to advise users about the smear microscopy collection can be noted (mean $=3.6$ ), as well as the storage and transportation of the sputum to the healthcare unit (mean=3.4) (Figure 1).

Legend: A - identification of tuberculosis RS in the community and healthcare services; B - active case finding at home visits; $\mathrm{C}$ - taking a smear microscopy referral to the user in their territory; $\mathrm{D}$ - showing users how to collect sputum; E - showing users how to store and send the sputum jar; $F$ - informing nurses about the RS identified in their territory; G - RS investigation based on confirmed cases of TB in the community. 


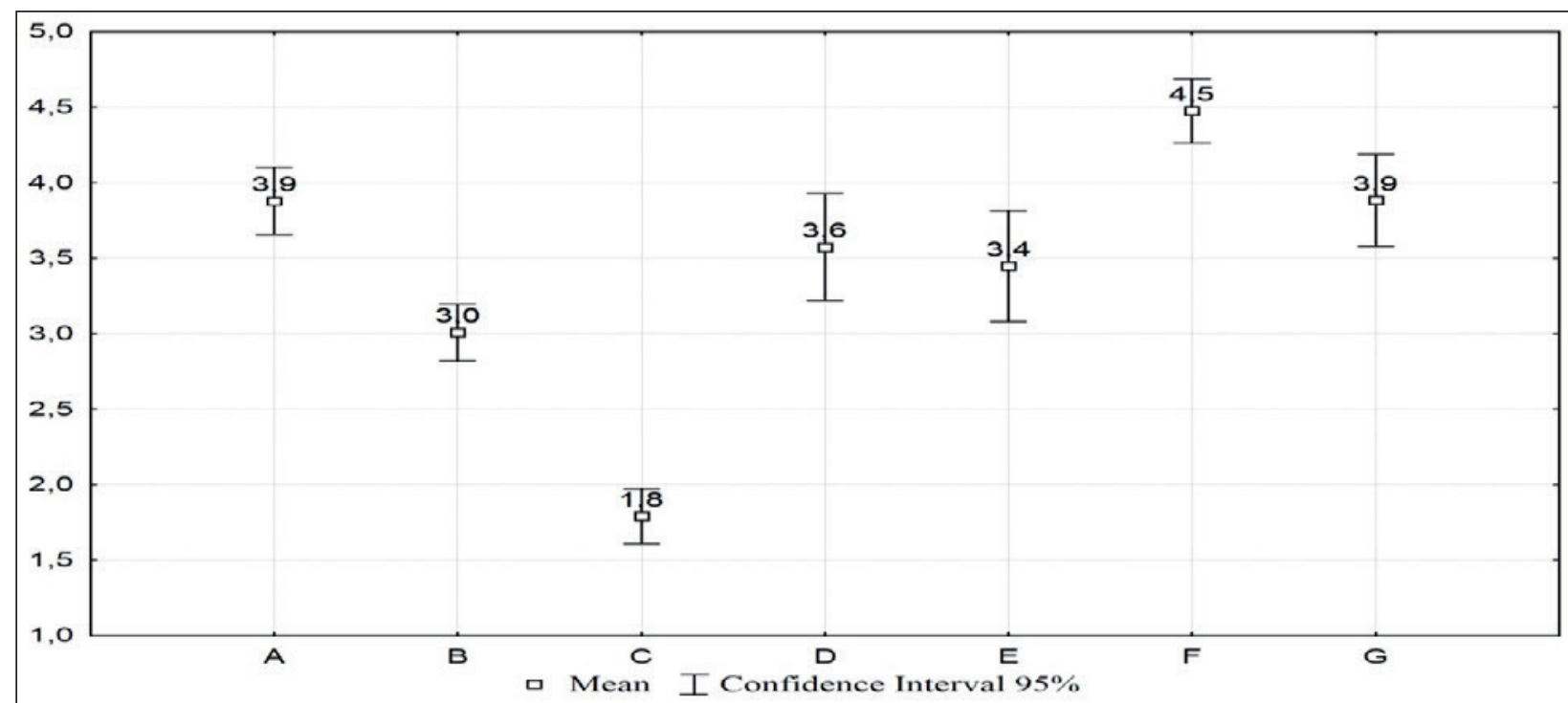

Figure 1 - Distribution of the means and confidence intervals of the indicators related to the work of the Community Health Workers in the search for respiratory symptoms in Ribeirão Preto-SP, based on individual care, June 2009 - Jan 2010

Concerning collective care, weaknesses in establishing discussions with the community about TB were identified (mean=1.5), as well as partnerships with the community for the ACF (mean=1.9), and the $\mathrm{CHWs}$ reported a lack of articulation with the social resources present in the territory where the healthcare units are a part of. Another weakness identified in the study relates to the health education about TB (mean=3.5) (Figure 2).

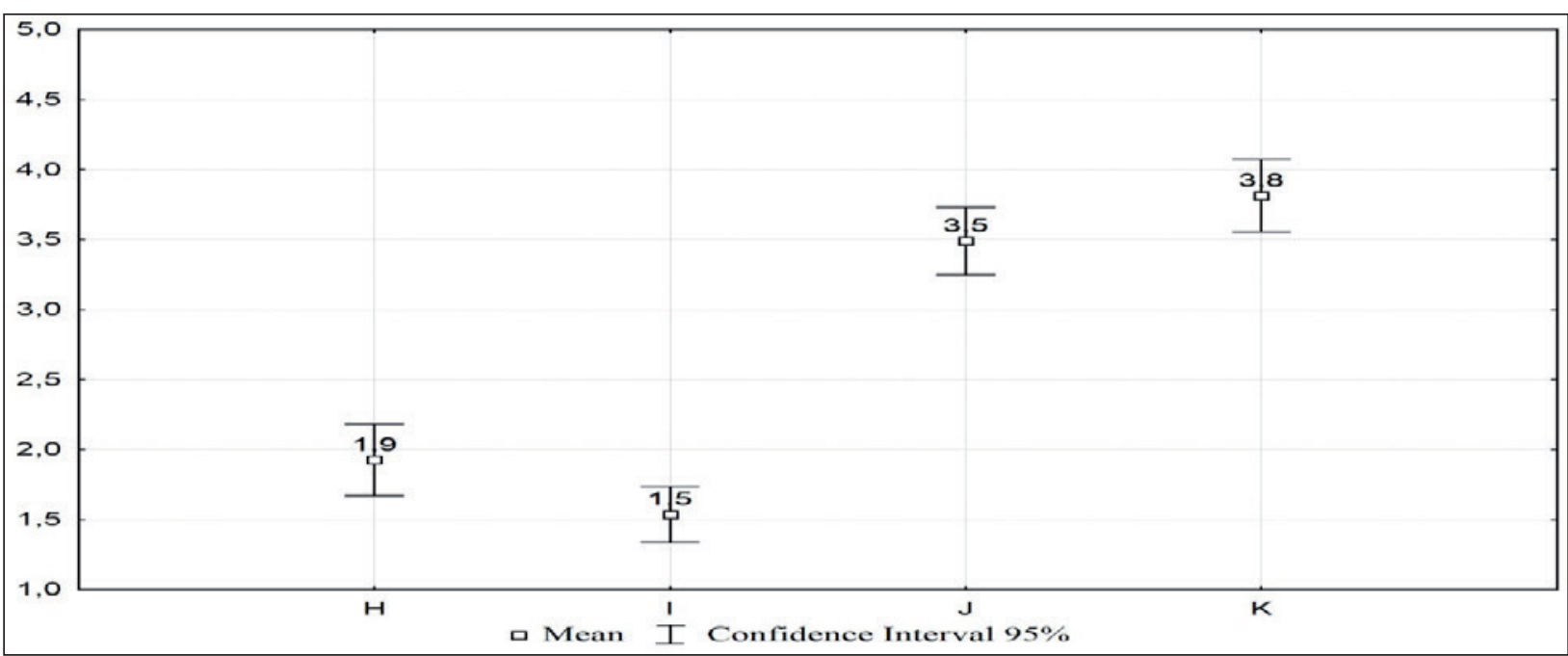

Legend: H - Partnership with the community in the ACF; I - Discussion with the community about TB; J - Health education about TB within the community; K - Participation in discussions with the team about actions to control the disease; L - Support from other healthcare professional working in the same service in a situation of suspected TB.

Figure 2 - Distribution of the means and confidence intervals of the indicators related to the work of the Community Health Workers in the active case finding in Ribeirao Preto, based on collective care, June 2009 - Jan 2010

Concerning the examined RS, only $6 \%$ (115) of the population in the areas covered by the health- care units studied were examined in 2009, which can lead to the conclusion that approximately 1,729 
RS were not investigated. The West and North districts, with higher rates of TB in the city, had very low proportion of RSs investigated $(6 \%$ and $2 \%$, respectively), while the Central, East and South districts had $14 \%, 11 \%$ and $8 \%$ of RSs investigated, respectively. It can be noted that, among the districts with higher TB rates, three healthcare units did not investigate any RS throughout the year 2009.

\section{DISCUSSION}

The characterization of the CHWs in this study is consistent with that of other studies, ${ }^{18-19}$ with the predominance of female and level of education higher than elementary school, which is recommended by the Ministry of Health. ${ }^{20}$

The highest level of education of the CHWs may increase the incorporation of new knowledge, assist in advising families under their responsibilities $^{21}$ and improve the recognition of the health needs of the population, thus being an important requirement to work within the community. However, even though the CHWs in this study had a good level of education, some indicators, such as: "investigation of the RSs at home visits" and "health education about TB in the community", were not satisfactory. This fact may be related to the model introduced by the $\mathrm{CHC}$ in relation to the manner in which training about TB is conducted, focused on more conventional discussions about the illness process, and therefore limited to the signs and symptoms of the disease, characterizing the predominance of the biomedical model in the healthcare area. This model, in conjunction with a centralization of training with little or no return to the CHWs, may be one of the elements that support the difficulties in relation to the indicators previously discussed.

In 2009, the CHC of the studied city held seminars centered on TB to all healthcare professionals in the network but there were approximately 80 participants. It is important to note that, generally, the information provided in the training events were not retransmitted to the other members of the teams, and that this only occurred when there was a TB case in the area covered or upon request. This combination may discourage the ACF in the territory and not inspire the CHWs for a new health order, since the professionals who should be multiplying the training received at the central level are not doing this, and this may not raise ethical and political commitment in the CHWs and other professionals in relation to the health issues in the territory.
To ensure specific knowledge and skills to perform the role of the CHWs, particularly in relation to the $\mathrm{ACF}$, the training must take place with adoption of a critical and reflective educational action, able to address the reality of the practice and the changes in health, and not one that is disconnected from the daily work in which the real circumstances of the communities are experienced. ${ }^{3,5}$

From this perspective, the proposal of the Continuous Health Education (CHE) is considered essential for the qualification of the healthcare teams, organized in accordance with the health needs of the population. This prerogative has the work process as object of change, in which workers can establish effective coping strategies, in conjunction with the team and the community. ${ }^{22}$ Therefore, the CHE may be an important tool for the control of TB in so far as everyone involved in the issue in the territory is responsible for it (management, education, service and social control) and, in their political and social environment, can clearly define the best coping strategy for their problem. This set up might substantially contribute to the ACF in the community and for the PHC to play its political and social role as the gateway to the RS of TB. In this sense, health education in the context of the territory, which may take place through the nursing supervision, can encourage a better performance on the part of the CHWs who, if committed with the health issues of the territory, could expand the responsibility range in the ACF.

Also in relation to the organization of the activities with the healthcare teams, concerning the work of the CHWs towards the investigation of the RS at the home visits considered as "regular" score, and providing users in the territory with a request for smear microscopy, considered "unsatisfactory", there is a difficulty in implementing actions that could lead to a better result in the investigation process of the RS of TB, since the CHWs believe that they are able to identify them in the community and in the healthcare services.

This discrepancy reflects the organizational manner of the PHC in relation to the assistance provided to $\mathrm{TB}$, given that it restricts the actions that could be offered by the CHWs. This resonates when the CHWs are advised to forward the suspect to the healthcare unit for a smear microscopy. This model of assistance imposes a bureaucratization process in the work of the CHWs that interferes with the ACF and increases the low performance of the healthcare units involved in the study concerning the examined RS, which was 
$6 \%$ of the RS expected in the areas covered in the studied city. It is important to consider that the responsibility of the entire healthcare team is not being exempted in this activity; however, given the particularities of the work of the CHWs with the community, this could be an extended strategy to improve the suspected TB rates in the territory.

In this sense, this form of organization may also directly affect some collective actions under the responsibility of the CHWs, such as the partnerships with the community for the ACF and the discussion with the communities about TB, considered "regular and unsatisfactory", which leads to the assumption that the lack of autonomy on the part of the CHWs to initiate an investigatory process of RS may be a motivational element that affects the development of these collective actions. In this sense, studies mention that the collective actions performed by the CHWs need strengthening concerning the valorization and community development, as well as the educational and preventive actions that positively affect the health of the community. ${ }^{23-24}$

Such limitations cease to involve a communicative action in the society, the ongoing dialogue of the existing social groups and people in general, which would seek the restructure of the collective action in support to the health and improvement of the living conditions, reinforcing the new care model proposed by the Integral Health Care, ${ }^{25-26}$ that is, people viewed in their biological, psychological and social dimensions. ${ }^{27}$

Authors point out that, although the CHWs seek to work with health promotion actions in order to legitimize their work, the healthcare team sometimes disqualify the care actions of the CHWs when they do not recognize in them the skills for the development of care that is different from that focused on the programmatic logic, restricting them to the repetition of the current model. ${ }^{28}$ These results confirm the findings of this study which show that, although the CHWs feel prepared to develop some practices required for the TB control, their execution was shown to be insufficient, perhaps due to the difficulty of the teams in valuing the worker in the development of individual and collective actions for the active search of TB suspects.

The action of health education about TB in the communities provided by the CHWs showed good performance in the studied city, but there were weaknesses in the articulation of the discussions about TB between the CHWs and the community and in the partnerships with the community for the ACF. This contradiction may be related to the view that the $\mathrm{CHW}$ s have about health education, to the extent that the non-establishment of bonds and articulation with the community in the discussions about TB seem to indicate that the transfer of knowledge, passivity and little autonomy are key elements that involve the educational process. This understanding about education can be one of the obstacles for the consolidation of a new care model, since the CHWs are not able to encourage the organization of the community to exercise their citizenship and the inclusion into a social change dimension, ${ }^{5}$ thus reproducing in the community the care model of the healthcare unit they are linked to.

Concerning the support of the healthcare team members to the CHWs, satisfactory scores were identified in relation to the support given by another healthcare professional of the unit in which they work in circumstances of suspected $\mathrm{TB}$ and in relation to the act of informing nurses about the RS identified in the territory. These two indicators show that the CHWs are able to identify a professional from the healthcare team as a reference for the development and support of their activities, and this is generally the nurse. However, the weaknesses in the articulation with the community show that, due to the fact that they do not hold a specific field of knowledge that allows them more work autonomy, ${ }^{5}$ which is necessary for these collective actions, they would need supervision for their development, since the work with the community requires a specific methodology.

It is important to note that the supervision of the CHWs is the nurses' responsibility, generally performed regularly once a week, as also seen in the scenario of this study, which may not provide enough time for discussions about health issues in the territory and areas under the competence of the CHWs. Therefore, it appears that the lack of time for continuous supervision may cause difficulties in the process and operationalization of the ACF by the CHWs.

In addition to nurse supervision and support from staff members, the discussions about the TB control actions in the PHC units are important forums to exchange experiences and seek solutions based on the healthcare needs of the population. Periodic discussions with all staff members support the exchange of ideas, the consolidation of the bond and the search for solutions to the difficulties 
experienced. ${ }^{29}$ Thus, supervision, in conjunction with internal discussions about issues related to TB need to go beyond healthcare services to ensure partnerships with the community and allow the construction of a new care model, in which the work focused on TB is a process connected to health surveillance, not only in regards to occasional activities resulting from campaigns.

Based on this, the CHWs have an important political role related to the organization of the community and change of their conditions; ${ }^{5}$ however, in this study, their performance in the actions of ACF was more connected to the technical dimension, related to the care provided to patients and their families, reproducing the biomedical model existent in the healthcare services and reinforcing the difficulties in the reorientation of the model focused on health surveillance. In relation to TB, the political dimension of the work performed by the CHWs is sine qua non condition when the TB control in the community is definitely intended. ${ }^{30}$

\section{CONCLUSION}

There is strong evidence that the current care model limits the development of a more collective work, articulated with the real needs of the community. This is reproduced in the micro space of the CHWs' work, restricting the actions recommended by the Ministry of Health for the investigation of $\mathrm{TB}$, and is reflected in an activity more focused on the technical rather than the political dimension.

The weaknesses found in relation to the supervision of nurses and qualification of the CHEs contribute to the low value given to the incorporation of the ACF actions in the routine of the healthcare services, thereby contributing for the $\mathrm{TB}$ to continue being a problem and a challenge for Public Health. In this sense, the political commitment and the need to promote further investments in the CHE are essential for a new TB care model, valuing the CHWs as unique members of the healthcare team for the ACF in the territory.

The study has limitations in that only the perception of the CHWs in relation to their skills and practice to perform the ACF is presented, and these aspects may be overestimated by them. Another limiting factor is related to the use of secondary data (number of required sputum smear microscopy for diagnosis) made available by the local laboratory, which not always was properly completed. Furthermore, it was not possible to capture the subjectivity related to the work of the $\mathrm{CHWs}$ together with the healthcare team, which would be possible through a qualitative approach.

\section{ACKNOWLEDGMENTS}

To the National Council for Scientific and Technological Development, process 575386/2008 8 , for the sponsorship of the research, and to the São Paulo Research Foundation, process n. 2009/12016-3.

\section{REFERENCES}

1. Ministério da Saúde (BR). Secretaria das Políticas Públicas. Departamento de Atenção Básica. Coordenação Nacional de Pneumologia Sanitária. Plano de controle da tuberculose no Brasil no período de 2001-2005. Brasília (DF): MS; 2000.

2. Teixeira G. O controle da tuberculose e a saúde da família. Perspectivas de uma parceria. Bol Pneumol Sanit. 2000 Dez; 8(2):3-4.

3. Nunes MO, Trad LB, Almeida BA, Homem CR, Melo MCIC. O Agente Comunitário de Saúde: construção da identidade desse personagem híbrido e polifônico. Cad Saúde Pública. 2002 Nov-Dez; 18(6):1639-46.

4. Haines A, Sanders D, Lehmann U, Rowe AK, Lawn JE, Jan S, et al. Achieving child survival goals: potential contribution of community health workers. Lancet. 2007 Jun; 369:2121-31.

5. Silva JA, Dalmaso ASW. Agente Comunitário de Saúde: o ser, o saber, o fazer. Rio de Janeiro (RJ): Fiocruz; 2002.

6. Clarke M, Dick J, Zwarenstein M, Lombard CJ, Diwan VK. Lay health worker intervention with choice of DOT superior to standard TB care for farm dwellers in South Africa: a cluster randomised control trial. Int J Tuberc Lung Dis. 2005 Jun; 9(6):673-9.

7. Datiko DG, Lindtjorn B. Health extension workers improve tuberculosis case detection and treatment success in southern ethiopia: a community randomized trial. PLoS ONE. 2009 May; 4(5):1-7.

8. Kiefer E, Shao T, Carasquillo O, Nabeta P, Seas C. Knowledge and attitudes of tuberculosis management in San Juan de Lurigancho district of Lima, Peru. J Infect Dev Ctrie. 2009; 3(10):783-8.

9. Wright J, Walley J, Philip A, Pushpananthan S, Dlamini E, Newell J, et al. Direct observation of treatment for tuberculosis: a randomized controlled trial of community health workers versus family members. Trop Med Int Health. 2004 May; 9(5):559-65.

10. Muniz JN, Palha PF, Monroe AA, Gonzales RC, Ruffino-Netto A, Villa TCS. A incorporação da busca ativa de sintomáticos respiratórios para o controle 
da tuberculose na prática do Agente Comunitário de Saúde. Cien Saúde Colet. 2005. Abr-Jun; 10(2):315-21.

11. Nogueira JA, Ruffino-Netto A, Monroe AA, Gonzales RIC, Villa TCS. Busca ativa de sintomáticos respiratórios no controle da tuberculose na percepção do Agente Comunitário de Saúde. Rev Eletrôn Enferm [online]. 2007 Jan-Abr; 9(1):106-18. [acesso 2009 Mai 15] Disponível em: http://www.fen.ufg. br/fen_revista/v9/n1/v9n1a08.htm

12. Maciel ELN, Vieira RCA, Milani EC, Brasil M, Fregona G, Dietze R. O Agente Comunitário de Saúde no controle da tuberculose: conhecimentos e percepções. Cad Saúde Pública. 2008 Jun; 24(6):1377-86.

13. Ribeirão Preto. Prefeitura Municipal. Secretaria Municipal de Saúde. Relatório de Gestão Ano 2009. [acesso 2010 Mai 31]. Disponível em: http:// www.ribeiraopreto.sp.gov.br/ssaude/i16principal. php?pagina=/ssaude/conselho/i16ind-gestao.htm

14. Ministério da Saúde (BR). Secretaria de Atenção à Saúde. Departamento de Atenção Básica. Política Nacional de Atenção Básica. Brasília (DF): MS; 2006.

15. Ministério da Saúde (BR). Secretaria de Políticas de Saúde. Tuberculose: informações para Agentes Comunitários de Saúde. Brasília (DF): MS; 2001.

16. Ministério da Saúde (BR). Secretaria de Vigilância em Saúde. Programa Nacional de Controle da Tuberculose. Manual de recomendações para o controle da tuberculose no Brasil.. Brasília (DF): MS; 2010.

17. Teixeira CF, Pinto LL, Vilas Boas ALQ. O Processo de trabalho da vigilância em saúde. Rio de Janeiro (RJ): Fiocruz/EPSJV/Proformar, 2004. 60p.

18. Ministério da Saúde (BR). Fundação Oswaldo Cruz. Saúde da família: avaliação da implementação em dez grandes centros urbanos: síntese dos principais resultados. 2. ed. Brasília (DF): MS, Fundação Oswaldo Cruz; 2005.

19. Pinto ESG, Menezes RM, Villa TCS. Situação de trabalho dos profissionais da Estratégia de Saúde da Família em Ceará-Mirim. Rev Esc Enferm USP. 2010 Set; 44(3):657-64.

20. Ministério da Saúde (BR). Proposta de formação do Agente Comunitário de Saúde - Habilitação
Profissional Técnica. Brasília (DF): MS; 2004.

21. Ferraz L, Aerts DRGC. O cotidiano de trabalho do Agente Comunitário de Saúde no PSF em Porto Alegre. Cien Saúde Colet. 2005 Abr-Jun; 10(2):347-55.

22. Massaroli A, Saupe R. Distinção conceitual: educação permanente e educação continuada no processo de trabalho em saúde. Santa Catarina, 2008 [acesso 2010 Nov 16]. Disponível em: http:/ / www. abennacional.org.br/2SITEn/Arquivos/N.045.pdf

23. OliveiraSAC, Ruffino Netto A, Villa TCS, Vendramini SHF, Andrade RLP, Scatena LM. Serviços de saúde no controle da tuberculose: enfoque na família e orientação para a comunidade. Rev Latino-Am Enferm. 2009 Mai-Jun; 17(3):361-7.

24. Oliveira RG, Nachif MCA, Matheus MLF. O trabalho do Agente Comunitário de Saúde na percepção da comunidade de Anastácio, Estado do Mato Grosso do Sul. Acta Scient Health Sciences. 2003 Jan-Jun; 25(1):95-101.

25. Merhy EE. Em busca do tempo perdido: a micropolítica do trabalho vivo em saúde. In: Merhy EE, Onocko R, organizadores. Agir em saúde: um desafio para o público. São Paulo (SP): Hucitec/ Lugar Editorial, 1997:385.

26. Minayo MCS. Estrutura e sujeito, determinismo e protagonismo histórico: uma reflexão sobre a práxis da saúde coletiva. Cien Saúde Colet. 2001; 6(1):7-19.

27. Morosini MVGC, Corbo AD'A. organizadores. Modelos de atenção e a saúde da família. Rio de Janeiro (RJ): EPSJV/Fiocruz; 2007.

28. Ferreira VSCF, Andrade CS, Franco TB, Merhy EE. Processo de trabalho do Agente Comunitário de Saúde e a reestruturação produtiva. Cad Saúde Pública. 2009 Abr; 25(4):898-906.

29. Campinas LLSL, Almeida MMMB. Agentes Comunitários de Saúde e o acolhimento aos doentes com tuberculose no Programa Saúde da Família. Bol Pneumol Sanit. 2004; 12(3):145-54.

30. Macq J, Torfoss T, Getahun H. Patient empowerment in tuberculosis control: reflecting on past documented experiences. Trop Med Int Health. 2007 Jul; 12(7):873-85. 